\title{
Fertiliser nitrogen effects on hill pasture and on grazing by ewes
}

\author{
A.G. GILLINGHAM ${ }^{1}$, M.H. GRAY ${ }^{2}$ and S. MACMILLAN ${ }^{2}$ \\ ${ }^{1}$ AgResearch, Grasslands Research Centre, P B 11008, Palmerston North \\ ${ }^{2}$ AgResearch, Poukawa, P. O. Box 8144, Havelock North \\ allan.gillingham@agresearch.co.nz
}

\begin{abstract}
A study was conducted on seasonally dry hill pastures near Waipawa, central Hawkes Bay, over a two year period to investigate how the application of nitrogen $(\mathrm{N})$ fertiliser changed the pasture chemical and species composition and if animals subsequently preferentially grazed that pasture.
\end{abstract}

In Year 1 the short term effects of $\mathrm{N}$ fertiliser $(30 \mathrm{~kg}$ $\mathrm{N} / \mathrm{ha}$ ) was evaluated on both north and south facing slopes after the pasture was spelled for about 12 to 25 days only after $\mathrm{N}$ fertiliser application. This period did not allow sufficient time for pasture dry matter (DM) responses to develop. In Year 2, using the same trial sites, the pasture was allowed to develop DM response differences of $500 \mathrm{~kg} / \mathrm{ha}$ or more following $\mathrm{N}$ fertiliser application before animals commenced grazing. On each occasion, grazing observations were made during a 5 hour period following stock introduction to spelled pasture. Herbage mass per plot was measured prior to, and at the end of the grazing period, and the amounts of pasture utilised per plot calculated.

In Year 1 there were three separate measurements and grazing observations. The first was in mid winter on pasture with a high dead matter and near zero clover content and overall low quality. $\mathrm{N}$ fertiliser had no effect on chemical composition. In the second and third observations in late July and September respectively, when more clover and less dead matter was present, $\mathrm{N}$ and crude protein $(\mathrm{CP})$ concentrations were both enhanced by earlier $\mathrm{N}$ fertiliser application. Similarly in 2003 when herbage mass responses were allowed to accumulate following $\mathrm{N}$ fertiliser application, the pasture $\mathrm{N}$, phosphorus, potassium and CP levels all increased and soluble sugars and starch levels decreased. These effects were more pronounced in the pasture from the south than from the north aspect.

In Year 1 there were no differences between Nfertilised and non-fertilised plots in mean grazing intensity $\left(\mathrm{ewes} / 100 \mathrm{~m}^{2}\right)$, or in the amounts of pasture DM utilised during grazing. In Year 2, grazing intensities and the amounts of pasture utilised, were higher where pasture mass was significantly higher as a result of $\mathrm{N}$ fertiliser application. The results suggested that where significantly greater pasture DM responses are allowed to occur, the subsequent grazing intensities will also be greater compared with grazing intensities on associated pasture. It is likely that the differences in pasture chemical composition induced by application of $\mathrm{N}$ fertiliser at 30 $\mathrm{kg} / \mathrm{ha}$ were insufficient to cause any difference in grazing behaviour by ewes. Higher $\mathrm{N}$ fertiliser rates may be required to induce such chemical changes and grazing preferences as observed in other studies.

Keywords: grazing intensity, nitrogen fertiliser, pasture quality, pasture species

\section{Introduction}

It has been long recognised that grazing animals prefer clover to grass in a mixed pasture (Parsons et al. 1994; Cosgrove et al. 1995). This has been attributed to a number of factors including both the higher digestibility (Ulyatt et al. 1988) and protein, or nitrogen (N) content, of the clover. This is related to the need for the protein:energy ratio to be in balance if feed is to be efficiently digested (CSIRO 1994). In controlled studies, Cosgrove et al. (1999) showed that grass with an elevated $\mathrm{N}$ content as a result of urea fertiliser application, was also preferentially grazed by sheep when offered the choice between grass of low and higher $\mathrm{N}$ content. However this preference did not exist when clover was also present. Hill pastures are characteristically low in legume content and there is increasing interest in the use of $\mathrm{N}$ fertiliser as an alternative $\mathrm{N}$ source for grass growth. Large pasture growth responses to $\mathrm{N}$ fertiliser have been measured in both moist (Lambert et al. 2003) and dry (Gillingham et al. 1998) hill country. There are however some reports by farmers of preferential grazing of such $\mathrm{N}$ fertiliser treated hill pastures, and similar effects have been noted at the Waipawa research area where grazing ewes had a choice of $\mathrm{N}$-treated and untreated pasture. The net effect was that at the end of the grazing period pasture utilisation on the $\mathrm{N}$-treated pasture was more uniform and complete than in the non fertilised areas.

The possible role of $\mathrm{N}$ fertiliser in not only increasing pasture production, but inducing grazing animals to fully utilise hill pasture, is of considerable interest to hill farmers. If steep slopes in particular can be well grazed in early-mid spring, then this improves the opportunity to maintain pasture control throughout the period of fastest growth. This could result in associated higher pasture quality and better lamb growth rates than where rank pasture accumulates.

In order to evaluate some of these effects, grazing 
observations were made on hill pastures at the Waipawa research area in Central Hawkes Bay over a two year period.

\section{Methods}

The study area was comprised of opposing north and south-facing slopes of about $20^{\circ}$ and fenced into separate paddocks. The north aspect paddock area was 0.297 ha, and the south aspect paddock area was 0.212 ha. Within each paddock a trial area block of 6 plots was marked out. These had an area of $495 \mathrm{~m}^{2}(15 \mathrm{~m} \times 33 \mathrm{~m})$ each on the north facing slope, and an area of $340 \mathrm{~m}^{2}(10 \mathrm{~m} \times 34$ $\mathrm{m})$ each on the south facing slope. The trial plots therefore occupied a total of $2970 \mathrm{~m}^{2}$ area within the north aspect paddock, and $2040 \mathrm{~m}^{2}$ area within the south aspect paddock. Plot lengths were down-slope. Within each aspect two of the six plots were randomly allocated to receive $\mathrm{N}$ fertiliser application at the start of each study period.

\section{Year 1 (2002)}

The effects of $\mathrm{N}$ fertiliser on pasture quality and grazing preference were evaluated shortly after $\mathrm{N}$ application when no additional pasture growth in the fertilised areas had accumulated. Paddocks were grazed with cows and calves over March to April 2002 to condition the pastures. Urea was applied ( $30 \mathrm{~kg} \mathrm{~N} / \mathrm{ha})$ on 5 July and 12 days later ewes were put in each paddock and allowed to freely graze across plots (Observation 1). The number of ewes on each plot was recorded at 5 minute intervals during hour 1, 3 and 5 of the grazing period. Observations were repeated in study periods on 30 July (Observation 2) and 24 September (Observation 3). Average ewe numbers per plot during the 5 hour grazing was calculated and expressed as ewes $/ 100 \mathrm{~m}^{2}$. In the 2003 observations, ewes actively grazing on each plot were also recorded.

Prior to $\mathrm{N}$ fertiliser application a pilot grazing and observation was made within the two study paddocks to evaluate if there was any natural preference by grazing ewes for parts of the trial area. None was observed.

Prior to grazing by ewes (post-grazing in the early July trial only), pasture on each plot was sampled for analysis of acid detergent fibre (ADF), neutral detergent fibre (NDF), in-vitro organic matter digestibility (OMD), crude protein (CP), metabolisable energy (ME), soluble sugars and starch (SSS), N, phosphorus (P), potassium $(\mathrm{K})$, and manganese $(\mathrm{Mn})$ contents using NIRS procedures. Pasture N, CP, ME and OMD concentration results are presented for all studies. For other pasture parameters only those significantly responsive to $\mathrm{N}$ fertiliser application are shown in the results at each observation date. Broad category species composition (grass, clover, dead matter) was dissected from pasture samples on each plot and each component expressed as percentage by weight. The pasture contained negligible ryegrass and was dominated by browntop and associated native grass species.

Pasture mass was derived as the average of 10 rising plate readings per plot calibrated from 16 samples from across all plots cut to ground level, both prior to and following grazing.

Following each study, the areas were grazed to eliminate any rank ungrazed pasture. In this way any carryover effects were not accumulated through the study period.

\section{Year 2 (2003)}

In Year 2 the N-treated pasture was allowed to develop a dry matter (DM) response difference of about 500-800 $\mathrm{kg} / \mathrm{ha}$. The trial area was fertilised with basal P and S fertilisers in winter 2003 and $\mathrm{N}$ fertiliser applied to two new plots on each aspect, as in 2002, following grazing of pasture to residual levels of about $1200 \mathrm{~kg} \mathrm{DM} / \mathrm{ha}$. Pasture DM assessments were made before and after grazing as in the 2002 studies.

Grazing observation studies were made on 23 (north aspect) and 24 (south aspect) September 2003 (Observation 4) following $\mathrm{N}$ fertiliser application 35 days earlier. A total of 103 ewes with lambs at foot were introduced on to the north aspect site. This represented an average pasture allowance of $12 \mathrm{~kg} \mathrm{DM} /$ ewe. A total of 47 ewes with lambs at foot grazed the south aspect site. This represented an average pasture allowance of $15 \mathrm{~kg} \mathrm{DM} /$ ewe. Grazing behaviour was recorded as in the 2002 studies. A final grazing study was made on 10 November (Observation 5) following application of $\mathrm{N}$ fertiliser 25 days previously. Pasture chemical composition and species composition were measured as in 2002 .

All data were statistically analysed by ANOVA combining north and south aspects with two replicates of $\mathrm{N}$ application and four replicates of the control treatment on each aspect at each observation date. The design used was a nested design with the land comprising the two aspects used as blocks. As each aspect was not replicated, the effects of aspect could not be evaluated. However, the main effect of the treatment, and the interaction of treatment with aspect under the assumption that aspect was the principal difference between the two blocks was tested. In all cases, the interaction was not significant. Results for each aspect are presented with an estimate of the Least Significant Difference (LSD 5\%) between treatment means within aspects.

\section{Results}

\section{Pasture chemical and species composition}

In the first study (early-July 2002) pasture species composition was characterised by high proportions of 
Table 1 Effects of $\mathrm{N}$ fertiliser ( $30 \mathrm{~kg} / \mathrm{ha}$ ) on pre-grazed hill pasture characteristics on north- and south-facing aspects in winter and spring 2002.

\begin{tabular}{|c|c|c|c|c|c|c|}
\hline & \multicolumn{2}{|c|}{ North - } & \multicolumn{2}{|c|}{ South } & \multirow[t]{2}{*}{$\begin{array}{l}\mathrm{N} \text { fert } \\
\text { Signif. }\end{array}$} & $\operatorname{LSD}(5 \%$ \\
\hline $\begin{array}{l}\text { Early-July } 2002 \\
\quad(12 \text { days after } \mathrm{N} \text { fertiliser }) \\
\text { Pasture species }\end{array}$ & No $N$ & N12 & No $N$ & $\mathrm{~N} 12$ & & \\
\hline Grass (\%) & 58 & 30 & 49 & 52 & NS & 29.1 \\
\hline Clover (\%) & 0 & 1 & 0 & 1 & NS & 1.5 \\
\hline Dead $(\%)$ & 42 & 69 & 50 & 47 & NS & 29.6 \\
\hline \multicolumn{7}{|l|}{ Pasture quality } \\
\hline$N(\%)$ & 1.55 & 1.69 & 2.07 & 2.37 & NS & 0.430 \\
\hline $\mathrm{CP}(\%)$ & 11.6 & 11.6 & 13.7 & 11.6 & NS & 3.21 \\
\hline ME (MJ/kg DM) & $<7$ & $<7$ & $<7$ & $<7$ & NA & \\
\hline OMD $(\%)$ & $<50$ & $<50$ & $<50$ & $<50$ & NA & \\
\hline \multicolumn{7}{|l|}{ Late-July 2002} \\
\hline \multicolumn{7}{|l|}{ Pasture species } \\
\hline Grass (\%) & 57 & 70 & 64 & 57 & NS & 15.6 \\
\hline Clover (\%) & 6 & 7 & 1 & 1 & NS & 6.0 \\
\hline Dead $(\%)$ & 37 & 23 & 35 & 42 & NS & 14.8 \\
\hline \multicolumn{7}{|l|}{ Pasture quality } \\
\hline N (\%) & 2.00 & 2.81 & 2.89 & 2.94 & ** & 0.368 \\
\hline $\mathrm{CP}(\%)$ & 12.5 & 16.8 & 18.6 & 20.1 & ** & 1.00 \\
\hline ME (MJ/kg DM) & $<7$ & $<7$ & $<7$ & $<7$ & NA & \\
\hline OMD $(\%)$ & $<50$ & 51.7 & 55.0 & 55.0 & NA & \\
\hline \multicolumn{7}{|l|}{ September 2002} \\
\hline (12 days after $\mathrm{N}$ fertiliser) & No $\mathrm{N}$ & N12 & No $\mathrm{N}$ & $\mathrm{N} 12$ & & \\
\hline \multicolumn{7}{|l|}{ Pasture species } \\
\hline Grass (\%) & 75 & 75 & 78 & 76 & NS & 2.9 \\
\hline Clover (\%) & 7 & 2 & 2 & 4 & NS & 5.6 \\
\hline Dead $(\%)$ & 19 & 23 & 19 & 21 & NS & 5.9 \\
\hline \multicolumn{7}{|l|}{ Pasture quality } \\
\hline N (\%) & 1.89 & 2.25 & 2.76 & 3.49 & * & 0.620 \\
\hline $\mathrm{CP}(\%)$ & 15.0 & 16.2 & 18.2 & 21.8 & * & 2.35 \\
\hline ME (MJ/kg DM) & 8.2 & 8.4 & 9.2 & 9.6 & NS & 0.78 \\
\hline
\end{tabular}

${ }^{*} \mathrm{P}<0.05 ;{ }^{* *} \mathrm{P}<0.01 ;{ }^{* * *} \mathrm{P}<0.001$.

NS indicates means not significantly different.

NA statistical analysis not possible.

dead matter, and near zero clover contents in both $\mathrm{N}-$ treated and non-treated pasture on both aspects (Table 1). Of all the chemical composition characteristics measured, none were affected within the 12 day period by $\mathrm{N}$ fertiliser application. The ME values of $<7 \mathrm{MJ} / \mathrm{kg}$ DM indicated a generally poor pasture quality, no doubt related to the high dead matter content present.

In the second study (late-July 2002), the pasture clover content had improved on the north aspect, probably because of the warmer conditions there than on the south aspect, but dead matter content remained relatively high on both aspects. The proportions of grass, clover and dead matter were again unaffected 25 days after $\mathrm{N}$ fertiliser application. However the $\mathrm{N}$ content in pasture on the north aspect was enhanced by the $\mathrm{N}$ fertiliser application, as were both $\mathrm{N}$ and $\mathrm{CP}$ concentrations in pasture on the south aspect. The overall pasture quality, as reflected by the $\mathrm{ME}$ values (i.e. $\mathrm{ME}=<7 \mathrm{MJ} / \mathrm{kg}$
DM), was still low.

In September 2002 (Observation 3), there were again no effects on the species composition of $\mathrm{N}$ fertiliser application 12 days earlier. The $\mathrm{N}$ and $\mathrm{CP}$ levels were higher in only the pasture on the south aspect that received $\mathrm{N}$ fertiliser. The ME analysis indicated that pasture quality had improved compared with that in the two earlier observation periods, but was not affected by $\mathrm{N}$ fertiliser application.

In the Year 2 studies (Table 2) the effects of allowing a pasture dry matter response to develop following $\mathrm{N}$ fertiliser application, were not significant on pasture species composition in September. However there was a reduction in mean clover content of the $\mathrm{N}$ treated pasture in November. Neither the grass nor dead matter contents were affected.

Pasture N, P, K and CP contents were all significantly elevated on the south aspect in September 2003 following 
Table 2 Effects of $\mathrm{N}$ fertiliser ( $30 \mathrm{~kg} / \mathrm{ha}$ ) on pre-grazed hill pasture characteristics on north- and south-facing aspects in spring 2003.

\begin{tabular}{|c|c|c|c|c|c|c|}
\hline & \multicolumn{2}{|c|}{ North } & \multicolumn{2}{|c|}{ - South } & \multirow{2}{*}{$\begin{array}{l}\mathrm{N} \text { fert } \\
\text { Signif. }\end{array}$} & $\operatorname{LSD}(5 \%$ \\
\hline $\begin{array}{l}\text { September } 2003 \\
\quad(35 \text { days after } \mathrm{N} \text { fertiliser }) \\
\text { Pasture species }\end{array}$ & No $\mathrm{N}$ & N 35 & No $\mathrm{N}$ & N 35 & & \\
\hline Grass (\%) & 66 & 85 & 80 & 92 & NS & 20.2 \\
\hline Clover (\%) & 25 & 6 & 13 & 4 & NS & 24.8 \\
\hline Dead $(\%)$ & 9 & 9 & 7 & 4 & NS & 8.0 \\
\hline Pasture quality & & & & & & \\
\hline $\mathrm{N}(\%)$ & 2.89 & 3.29 & 3.25 & 3.98 & ** & 0.424 \\
\hline $\mathrm{P}(\%)$ & 0.40 & 0.43 & 0.47 & 0.51 & * & 0.043 \\
\hline $\mathrm{K}(\%)$ & 1.91 & 2.30 & 2.50 & 3.08 & *** & 0.200 \\
\hline $\mathrm{CP}(\%)$ & 16.2 & 18.4 & 18.3 & 23.4 & ** & 2.71 \\
\hline ME (MJ/kg DM) & 8.7 & 9.2 & 10.0 & 10.4 & NS & 0.60 \\
\hline OMD (\%) & 61.5 & 64.3 & 70.0 & 73.7 & NS & 4.25 \\
\hline SSS (\%) & 8.9 & 8.1 & 11.6 & 9.8 & ** & 1.08 \\
\hline $\begin{array}{l}\text { November } 2003 \\
\text { ( } 25 \text { days after } N \text { fertiliser })\end{array}$ & No $N$ & N25 & No $N$ & N25 & & \\
\hline Pasture species & & & & & & \\
\hline Grass (\%) & 66 & 81 & 75 & 82 & NS & 18.8 \\
\hline Clover (\%) & 7 & 2 & 14 & 3 & ** & 6.6 \\
\hline Dead (\%) & 26 & 17 & 11 & 15 & NS & 18.1 \\
\hline Pasture quality & & & & & & \\
\hline N (\%) & 2.07 & 2.35 & 2.36 & 2.82 & ** & 0.364 \\
\hline $\mathrm{CP}(\%)$ & 16.2 & 18.3 & 15.9 & 23.4 & ** & 2.52 \\
\hline ME (MJ/kg DM) & 8.0 & 9.2 & 10.0 & 10.4 & ** & 0.73 \\
\hline OMD (\%) & 61.5 & 64.3 & 70.0 & 73.7 & NS & 5.43 \\
\hline
\end{tabular}

$\mathrm{N}$ fertiliser application 25 days previously, whereas SSS was significantly depressed. Throughout the two year study period there were examples where the ratio of $\mathrm{CP}$ to SSS was $>2$. These were in both the $\mathrm{N}$ fertilised and non-fertilised pastures. Ratios of this magnitude are regarded as deleterious to animal health (CSIRO 1994).

Pasture K was the only parameter raised in the north aspect pasture following $\mathrm{N}$ fertiliser application.

In November 2003 the pasture clover content was depressed, and also N, CP and ME concentrations in pasture on the south aspect raised, by $\mathrm{N}$ fertiliser application. Metabolisable energy was elevated only on the north aspect at this time. The OMD and ME levels indicated that the pasture in both of the observations in 2003 was of average to good quality.

\section{Pasture utilisation and grazing intensity}

None of the grazing observation studies in 2002 showed differences in pasture utilisation between plots that had received no $\mathrm{N}$ fertiliser and those that had been fertilised up to 25 days previously (Table 3 ). At each observation date in 2002 the average numbers of ewes on unfertilised and $\mathrm{N}$ fertilised plots were generally similar when pregrazing pasture cover was also similar on all plots within each aspect.

In 2003 the pre-grazed pasture cover in September was considerably higher than would normally occur in hill pastures at this time of year, even following $\mathrm{N}$ fertiliser application (Table 4). However it represented an extreme example of both pasture cover and the difference in pasture DM response for this study. It was of interest therefore that the amounts of pasture utilised were greater from the $\mathrm{N}$ fertilised plots than from the untreated plots in only the September observation. In November 2003, when the initial pasture mass was lower, and the DM responses lower, the amounts utilised from $\mathrm{N}$-treated and non-treated pastures were similar. This was supported by the observed average grazing intensities which were significantly higher on the $\mathrm{N}$ treated plots in the September study but not in November.

\section{Discussion}

\section{Pasture species and nutrient composition}

At the start of the study period the pasture contained negligible clover, significant dead material and was of a generally low quality. This had changed little by lateJuly 2002 but quality indicators had shown some improvement by September and this continued through the two studies in 2003. The application of $\mathrm{N}$ fertiliser did not affect nutritional quality within either 12 or 25 days of application when initial ME was less than $7 \mathrm{MJ} /$ $\mathrm{kg} \mathrm{DM}$ and OMD was below $50 \%$. However as the general quality of the pasture improved in September 2002, $\mathrm{N}$ fertiliser significantly improved $\mathrm{N}$ and $\mathrm{CP}$ 
Table 3 Effects of $\mathrm{N}$ fertiliser (30 kg/ha) on pre-grazing cover, pasture utilisation ( $\mathrm{kg} \mathrm{DM} / \mathrm{ha})$, grazing intensity and ewes grazing (ewes/100m ${ }^{2}$ ) on north- and south-facing aspects in winter and spring 2002.

\begin{tabular}{|c|c|c|c|c|c|c|}
\hline \multirow[b]{2}{*}{ Early-July 2002} & \multicolumn{2}{|c|}{ North } & \multicolumn{2}{|c|}{ South } & \multirow{2}{*}{$\begin{array}{l}\mathrm{N} \text { fert } \\
\text { Signif. }\end{array}$} & \multirow[t]{2}{*}{$\operatorname{LSD}(5 \%)$} \\
\hline & & & & & & \\
\hline (12 days after $N$ fertiliser) & No $N$ & N 12 & No $N$ & N 12 & & \\
\hline Pre-grazing cover & 2222 & 2033 & 1558 & 1717 & NA & \\
\hline Pasture utilised & 842 & 900 & 488 & 691 & NA & \\
\hline Grazing intensity & 1.9 & 1.8 & 1.8 & 2.0 & NS & 0.40 \\
\hline \multicolumn{7}{|l|}{$\begin{array}{l}\text { Late-July } 2002 \\
\qquad(25 \text { days after } \mathrm{N} \text { fertiliser) }\end{array}$} \\
\hline Pre-grazing cover & 1661 & 1764 & 1364 & 1337 & NS & 433.2 \\
\hline Pasture utilised & 214 & 316 & 256 & 142 & NS & 240.1 \\
\hline Grazing intensity & 2.2 & 1.6 & 2.1 & 1.9 & NS & 0.66 \\
\hline Ewes grazing & & 1.8 & & 2.1 & & \\
\hline \multicolumn{7}{|l|}{$\begin{array}{l}\text { September } 2002 \\
\quad(12 \text { days after } \mathrm{N} \text { fertiliser) }\end{array}$} \\
\hline Pre-grazing cover & 2728 & 2712 & 2001 & 2268 & NSNS & 514.6 \\
\hline Pasture utilised & 347 & 348 & 531 & 515 & & 568.9 \\
\hline Grazing intensity & 1.7 & 1.5 & 1.7 & 1.8 & NS & 0.550 \\
\hline Ewes grazing & & 0.81 & & 0.98 & & \\
\hline
\end{tabular}

Table 4 Effects of $\mathrm{N}$ fertiliser ( $30 \mathrm{~kg} / \mathrm{ha}$ ) on pre-grazing cover, pasture utilisation ( $\mathrm{kg} \mathrm{DM} / \mathrm{ha})$, grazing intensity and ewes grazing (ewes/100m²) on north- and south-facing aspects in spring 2003.

\begin{tabular}{|c|c|c|c|c|c|c|}
\hline \multirow[b]{2}{*}{ September 2003} & \multicolumn{2}{|c|}{ North } & \multicolumn{2}{|c|}{ South $\longrightarrow$} & \multirow[t]{2}{*}{$\begin{array}{l}\mathrm{N} \text { fert } \\
\text { Signif. }\end{array}$} & \multirow[t]{2}{*}{$\operatorname{LSD}(5 \%$} \\
\hline & & & & & & \\
\hline (35 days after $\mathrm{N}$ fertiliser) & No $N$ & N 35 & No $\mathrm{N}$ & N 35 & & \\
\hline Pre-grazing cover & 3691 & 4497 & 3249 & 3754 & ** & 421.8 \\
\hline Pasture utilised & 742 & 1390 & 1765 & 2254 & $* \star *$ & 329.2 \\
\hline Grazing intensity & 2.6 & 2.4 & 0.7 & 2.41 & *** & 1.40 \\
\hline Ewes grazing & 0.8 & 0.4 & 0.6 & 0.7 & *** & 0.46 \\
\hline \multicolumn{7}{|l|}{$\begin{array}{l}\text { November } 2003 \\
\quad(25 \text { days after } \mathrm{N} \text { fertiliser })\end{array}$} \\
\hline Pre-grazing cover & 2498 & 3107 & 2759 & 3407 & $\star * \star *$ & 544.1 \\
\hline Pasture utilised & 1382 & 1625 & 1698 & 2054 & NS & 506.5 \\
\hline Grazing intensity & 2.5 & 2.9 & 1.6 & 2.5 & NS & 1.75 \\
\hline Ewes grazing & 0.65 & 0.75 & 0.59 & 0.86 & NS & 0.371 \\
\hline
\end{tabular}

contents, but in south aspect pastures only. In September and November 2003 the effects of $\mathrm{N}$ fertiliser application on pasture chemical composition were more pronounced and extensive within 35 days and 25 days respectively, but again predominantly in pasture on the south aspect. It appears then that pasture quality was not modified by $\mathrm{N}$ fertiliser, at least over 12-25 days in winter, when initial levels were low, but that where the pasture was actively growing, and pasture quality parameters were at a moderate level, then $\mathrm{N}$ uptake and associated pasture quality changes were more pronounced. This was supported by the greater responses from pastures on the south aspect, which had higher initial levels of most quality parameters, than pasture on the north aspect, and showed significant enhancements from $\mathrm{N}$ fertiliser application, whereas the north aspect pasture showed fewer such responses.

The measurement of CP: SSS ratios of $>2$ are likely to be of importance only if animals were subjected to this pasture type for extended periods. However in the context 
of these observations where the CP level was not high, toxicity effects (ARC 1980) would be extremely unlikely.

Significant changes in pasture species composition following $\mathrm{N}$ fertiliser application were unable to be detected, although there were consistent trends from September 2002 to November 2003, for a decrease in pasture clover content following $\mathrm{N}$ fertiliser application. It was evident that the variability in the species composition from plot to plot was a major feature of these pastures. The level of sampling intensity was insufficient to adequately cope with this variability.

\section{Pasture utilisation and grazing intensity}

The three observations in 2002 were to evaluate if any chemical changes in pasture composition as a result of $\mathrm{N}$ fertiliser application were sufficient to induce preferential grazing by ewes. None was observed. This was despite significantly enhanced $\mathrm{N}$ and $\mathrm{CP}$ contents of the $\mathrm{N}$ treated pastures in both late-July and in September 2002. Cosgrove et al. (2004) confirmed that sheep show a preference for high-N pastures when the alternative is low-N content grass. In their study the $\mathrm{N}$ contents of the grasses were $4.5 \%$ and $3.2 \%$ for high and low- $\mathrm{N}$ grasses respectively i.e. a difference of $1.3 \% \mathrm{~N}$. In these studies the differences in $\mathrm{N} \%$ between $\mathrm{N}$-treated and non treated pastures were less than $1 \%$ (Table 1).

In 2003, pasture DM responses were allowed to accumulate prior to grazing. The estimated amounts of pasture utilised by grazing ewes were higher from the $\mathrm{N}$-treated pastures than from untreated areas in only the September measurements. This was supported by the grazing intensity observations. The effects of $\mathrm{N}$ fertiliser on pasture quality components were more pronounced and extensive in September 2003 than in any other observation. These changes may have been factors in the higher amounts of pasture utilised from the treated plots but as discussed above it is probable that the extent of the changes were insufficient to cause this effect. There were no effects of $\mathrm{N}$ fertiliser on pasture species composition that could have contributed to these grazing intensity differences. In November 2003 the same grazing effects were not observed or measured.

\section{Conclusions}

Results have shown that the application of $\mathrm{N}$ fertiliser at $30 \mathrm{~kg} \mathrm{~N} / \mathrm{ha}$ can modify the chemical composition of hill pastures within 12 days, but not in situations where there is a high proportion of dead matter present and where the initial quality is very low.

The methodology employed in these observations was generally unable to detect any effects of $\mathrm{N}$ fertiliser application on pasture species composition. This is a reflection of inadequate replication of treatments and associated sampling intensity. However the methodology was able to detect significant changes in pasture chemical composition as a result of $\mathrm{N}$ fertiliser application. Pasture chemical composition was clearly much less variable than pasture species composition. This suggests that the species arrangement did not have a major effect on the average chemical composition of the pasture at any one time.

Results also indicated that, given choice, grazing ewes utilised more pasture from plots with a higher DM cover during the given grazing period. The significantly enhanced pasture chemical composition of the $\mathrm{N}$-induced greater dry matter is unlikely to have been a factor in this preference. Higher rates of $\mathrm{N}$ fertiliser application would be required to do this. The trials were conducted on pastures of relatively low nutritional quality, especially in 2002, but would have been similar to those existing on many hill country farms. It would be expected that similar results would be obtained on such properties.

Regardless of the actual mechanisms involved it is clear that where significant differences in pasture mass develop within a grazed area, that grazing ewes, given choice, will show a preference for such pasture. Such differences may develop in urine patches or from the differential application of $\mathrm{N}$ fertiliser. In these studies the grazing period and associated observations did not continue long enough to determine if there would be any differences in final residual pasture cover levels once available pasture became limiting. This would provide an added advantage in aiding the control of hill pastures.

\section{ACKNOWLEDGEMENTS}

These trials were funded by FertResearch. Statistical analysis assistance was provided by Fred Potter and Zaneta Park-Ng.

\section{REFERENCES}

ARC 1980. The nutrient requirements of ruminant livestock. Technical Review. Farnham Royal, UK Commonwealth Agricultural Bureaux. Ch 4: 121181.

Cosgrove, G.P; Anderson, C.B; Fletcher, R.H. 1995. Do cattle exhibit a preference for white clover? White clover: New Zealand's competitive edge. Agronomy Society of New Zealand Special Publication 11/ Grassland Research and Practice 16: 83-86

Cosgrove, G.P.; Parsons, A.J.; Brock, J.L.; Tilbrook, J.C. 2004. The role of herbage nitrogen concentration in the foraging strategies of sheep. Applied Animal Behaviour Science: in press.

CSIRO 1994. Feeding standards for Australian livestock: Ruminants. CSIRO Publications, East Melbourne, Victoria.

Gillingham, A.G.; Gray, M.H.; Smith, D. 1998. Pasture responses to phosphorus and nitrogen fertilisers on 
dry hill country. Proceedings of the New Zealand Grassland Association 60: 135-140.

Lambert, M.G.; Mackay, A.D.; Devantier, B. P.; McDougall, D.B.; Barker, D.J.; Park-Ng, Z.A. 2003. Redefining the production potential of hill pastures using nitrogen fertiliser. Proceedings of the New Zealand Grassland Association 65: 35-40.

Parsons, A.J.; Newman, J.A.; Penning, P.D.; Harvey,
A.; Orr, R.J. 1994. Diet preference of sheep: effects of recent diet, physiological state and species abundance. Journal of Animal Ecology 63: 465-478.

Ulyatt, M.J.; Thomson, D.J.; Beever, D.E.; Evans, R.T.; Haines, M.J. 1988. The digestion of perennial ryegrass (Lolium perenne. L. cv. Melle) and white clover(Trifolium repens L. cv Blanca) by grazing cattle. British Journal of Nutrition 60: 137-149. 
